TITLE:

\title{
RECENT THECATE AND FOSSILIZED DINOFLAGELLATES OFF HACHINOHE COAST, NORTHEASTERN JAPAN
}

$\operatorname{AUTHOR}(\mathrm{S})$ :

Matsuoka, Kazumi

\section{CITATION:}

Matsuoka, Kazumi. RECENT THECATE AND FOSSILIZED DINOFLAGELLATES OFF HACHINOHE COAST, NORTHEASTERN JAPAN. PUBLICATIONS OF THE SETO MARINE BIOLOGICAL LABORATORY 1976, 23(3-5): 351-369

ISSUE DATE:

1976-10-30

URL:

http://hdl.handle.net/2433/175931

RIGHT: 


\title{
REGENT THEGATE AND FOSSILIZED DINOFLAGELLATES OFF HAGHINOHE COAST, NORTHEASTERN JAPAN
}

\author{
KAZUMI MATSUÓKA \\ Department of Biology, Osaka City University
}

With Text-figures $1-2$ and Plates $I-I V$

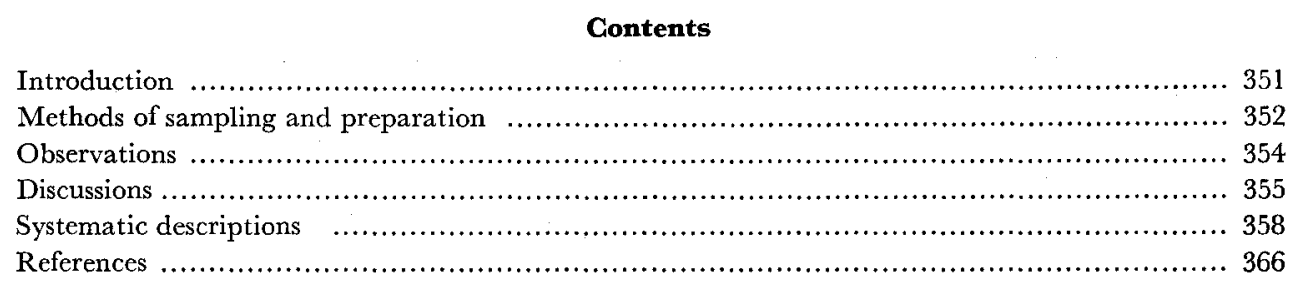

\section{Introduction}

It has long been known that a few species of dinoflagellates such as Ceratium hirundinella produce cysts or resting spores at a certain stage of the life cycle (Huber and Nipkow, 1922 and 1923 in Sarjeant, 1974). The fact, on the other hand, that the dinoflagellates obtained from bottom sediments including hystrichospheres in a narrow sense are fossilized cyst forms is recently clarified by Evitt (1963) and others. On the bases of these knowledges, much has been added to the information on the occurrence and distribution of the dinoflagellate cysts in the Pleistocene and Recent sediments (Rossignol, 1962; Wall, 1967; Wall, Dale and Harada, 1973; Reid and Downie, 1973; Harland, 1973; Reid, 1974; Davey and Rogers, 1975).

For the northwestern Pacific, Boulouard and Delauze (1966) first reported on the occurrence of dinoflagellate cysts referred to the fossil genera Leptodinium and Spiniferites accompanied by some acritarchs, Concentricystes and other various palynomorphs from the Japan Trench off Sendai (4,500 $\mathrm{m}$ in depth) and off Boso Peninsula $(9,200 \mathrm{~m}$ in depth). They were followed by Shimakura (1970) who preliminarily took the reports and found that Recent dinoflagellate assemblage in the sediments of the Sea of Japan was composed of many species of Operculodinium and Spiniferites with additional forms such as Nematosphaeropsis labyrinthea, Peridinium spp., and Tuberculodinium vancampoae. Then, Matsuoka and Nishida (1973) reported the occurrence of fossil dinoflagellate cysts such as Leptodinium, Spiniferites, Hemicystodinium, Hystrichokolpoma and Tuberculodinium from the Pliocene to Recent sediments off Kii Peninsula and off Shikoku, while Harada (1974, MS.) studied on the distribution of dinoflagellate cysts and acritarchs in Recent bottom sediments on the continental margins of the western North Pacific, mainly off Northeastern Japan.

Publ. Seto Mar. Biol. Lab., XXIII (3/5), 351-369, 1976.

(Article 25) 
Some authors, though they are not many, have discussed on the relationship between motile thecate dinoflagellates (generally in the planktonic life phase) and fossilized cysts in the bottom sediments from the same sampling areas. Reid (1972, 1974) treated of the distribution of the thecate and cyst forms of dinoflagellates around the British Isles. Davey and Rogers (op. cit.) also discussed on this relationship in their study about palynomorphs from the Recent sediments off South Africa.

Around the northwestern Pacific, on the other hand, there has been till now no reports dealing with this problem. The present article is prepared to describe the dinoflagellate assemblages of both thecate forms in the surface water and fossilized cysts in the bottom sediments collected from the same locations off Hachinohe, northeast coast of Honshu Island of Japan. Furthermore, the remarkable differences in their components as observed between the thecate and the cyst assemblages are discussed, and finally are given the brief descriptions of several cyst forms mainly of the genus Peridinium.

\section{Methods of Sampling and Preparation}

Both plankton net and dredged bottom samples were collected from off Hachinohe coast during the research cruise KT 73-5 made in May, 1973, by the MSV "Tansei Maru" of the Ocean Research Institute of the University of Tokyo. The plankton was sampled at the same stations as for the dredging by means of a plankton net (250 mesh) hauled up vertically from the depth of $50 \mathrm{~m}$ or $200 \mathrm{~m}$. The collected plankton was fixed with dilute formalin solution in $250 \mathrm{cc}$ polyethylene bottles, and preserved at room temperature. The water depth and surface water temperature at each station are given in Table 1 .

Table 1. Sampling data off Hachinohe in Cruise KT73-5 (May, 1973).

\begin{tabular}{rrrrrrr}
\hline Station & Latitude & Longitude & $\begin{array}{c}\text { Water } \\
\text { depth }\end{array}$ & $\begin{array}{c}\text { Surface } \\
\text { water temp. }\end{array}$ & $\begin{array}{l}\text { Bottom } \\
\text { sample }\end{array}$ & Net sample \\
\hline St. 1 & $40^{\circ} 36.6^{\prime} \mathrm{N}$ & $141^{\circ} 36.5^{\prime} \mathrm{E}$ & $62 \mathrm{~m}$ & $10.2^{\circ} \mathrm{C}$ & Dredge & $50 \mathrm{~m}$ (vertical) \\
St. 2 & $40^{\circ} 49.5^{\prime} \mathrm{N}$ & $142^{\circ} 02.0^{\prime} \mathrm{E}$ & $550 \mathrm{~m}$ & $9.2^{\circ} \mathrm{C}$ & Dredge & $200 \mathrm{~m}$ (vertical) \\
St. 3 & $40^{\circ} 53.7^{\prime} \mathrm{N}$ & $142^{\circ} 11.3^{\prime} \mathrm{E}$ & $1010 \mathrm{~m}$ & $9.4^{\circ} \mathrm{C}$ & Dredge & none \\
St. 4 & $41^{\circ} 12.8^{\prime} \mathrm{N}$ & $142^{\circ} 45.5^{\prime} \mathrm{E}$ & $1730 \mathrm{~m}$ & $7.0^{\circ} \mathrm{C}$ & Dredge & $200 \mathrm{~m}$ (vertical) \\
\hline
\end{tabular}

A large amount of phyto- and zooplankton was found from the surface samples. Among the former, diatoms especially Coscinodiscus spp. are very abundant and followed by dinoflagellates and silicoflagellates. In zooplankton samples are observed copepods, tintinnids and foraminifers in order of abundance. For removing larger organisms such as Coscinodiscus and copepods, the samples were sifted through a 100 mesh screen. In order to concentrate the dinoflagellates a smaller fraction was centrifuged and then mounted on a slide glass with glycerine jelly. The separation of cysts from the sediments was generally carried out according to Shimakura's method (1970). To avoid the destruction of some Peridinium cysts, especially those with single, thin and dark brownish wall, the samples were treated intentionally with 


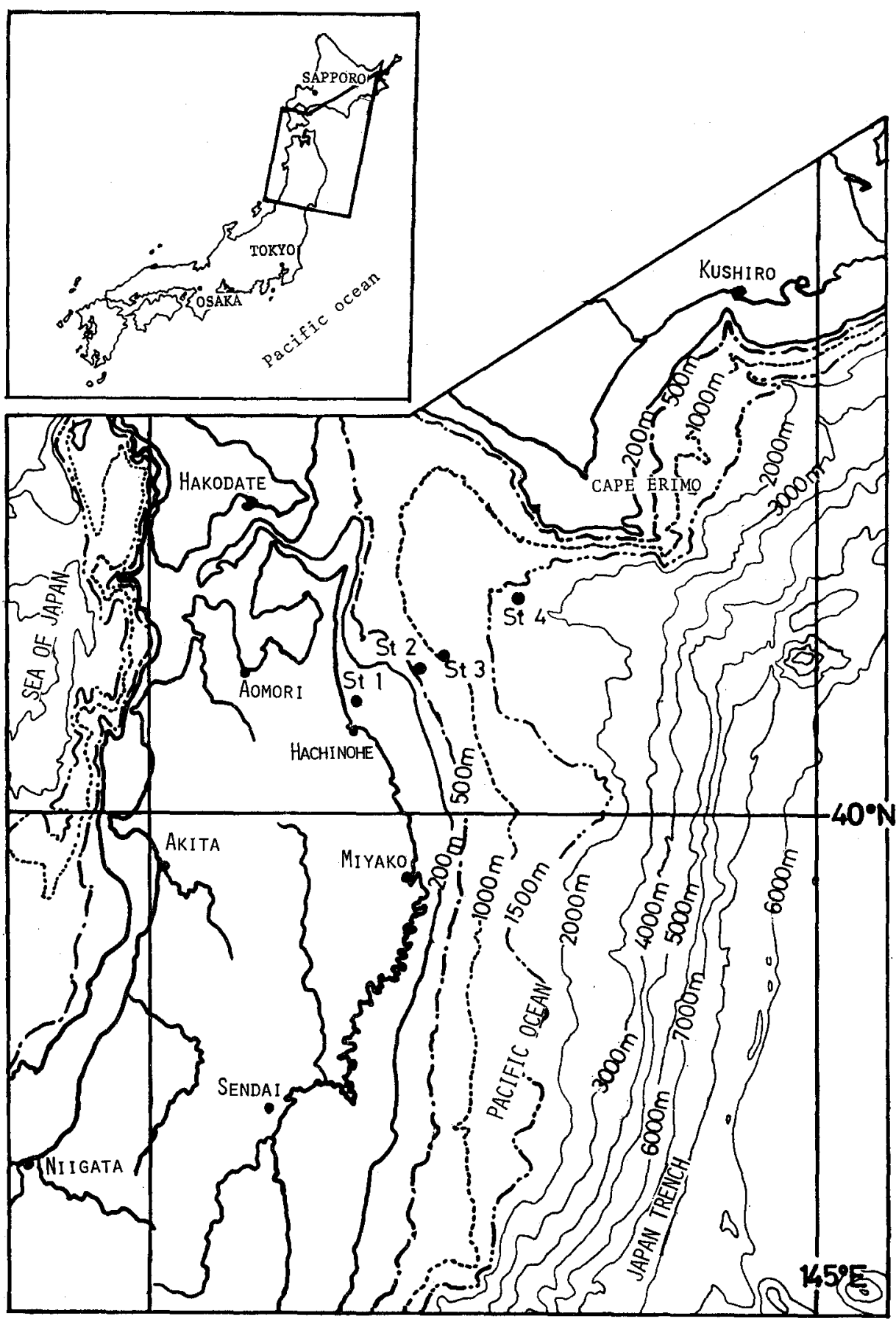

Text-fig. 1. Location of sampling stations together with bathymetric contours. 
much more dilute alkali solutions. Finally, as in the same with plankton samples, palynomorphs were concentrated and mounted on a slide glass with glycerine jelly.

The observation was done under an optical microscope and occasionally under a scanning electron microscope.

More than 200 individuals of both plankton forms and cysts were counted at random just as in the case of a pollen analysis.

The figured specimens and a part of the original samples of the present study are deposited in the Laboratory of Palaeobotany, Osaka City University.

\section{Observations}

The thecate and fossilized dinoflagellates obtained from both plankton and sediment samples off Hachinohe Goast are listed in Tables 2 and 3.

Table 2. List of dinoflagellate cysts collected from the bottom sediments off Hachinohe, northeastern Japan

\begin{tabular}{|c|c|c|c|c|}
\hline & St. 1 & St. 2 & St. 3 & St. 4 \\
\hline Leptodinium $\mathrm{sp}$. & & * & & $*$ \\
\hline Lingulodinium machaerophorum & & * & & $*$ \\
\hline Nematosphaeropsis labyrinthea & & & & $*$ \\
\hline Operculodinium centrocarpum & & * & * & $*$ \\
\hline Operculodinium islaerianum & & & & $*$ \\
\hline Peridinium conicoides & * & $*$ & $*$ & $*$ \\
\hline Peridinium? denticulatum & * & & & * \\
\hline Peridinium sp. cf. $P$. ? denticulatum & & & & $*$ \\
\hline Peridinium leonis & & $*$ & & $*$ \\
\hline Peridinium oblongum & & * & * & \\
\hline Peridinium sp. aff. $P$. oblongum & & $*$ & $*$ & \\
\hline Peridinium sp. cf. $P$. pentagonum & & * & & $*$ \\
\hline Peridinium sp. cf. $P$. punctulatum & & $*$ & & * \\
\hline Peridinium sp. cf. $P$. subinerme & & * & * & \\
\hline Peridinium sp. (Cyst-form A) & & $*$ & & $*$ \\
\hline Peridinium sp. (Cyst-form B) & & $*$ & & $*$ \\
\hline Peridinium sp. (Cyst-form C) & & $*$ & * & \\
\hline Peridinium sp. (Cyst-form D) & & & & $*$ \\
\hline Peridinium spp. & & * & * & $*$ \\
\hline Spiniferites bentori & & & $*$ & $*$ \\
\hline Spiniferites bulloideus & & * & * & \\
\hline Spiniferites mirabilis & & $*$ & $*$ & $*$ \\
\hline Spiniferites nodosus & & & & $*$ \\
\hline Spiniferites ramosus & & $*$ & & * \\
\hline Spiniferites spp. & & $*$ & $*$ & $*$ \\
\hline Tuberculodinium vancampoae & & $*$ & & \\
\hline
\end{tabular}

Table 3. List of pelagic dinoflagellates collected from the surface plankton off Hachinohe, northeastern Japan

\begin{tabular}{lccc}
\hline & St. 1 & St. 2 & St. 4 \\
\hline Ceratium articum & $*$ & $*$ & $*$ \\
Ceratium bucephalum & $*$ & $*$ & \\
Ceratium fusus & $*$ & $*$ & \\
Ceratium kofoidii & $*$ & & \\
Ceratium spp. & & $*$ & $*$ \\
Diplopsalis lenticula & & & $*$ \\
Gonyaulax sp. indet. & & & $*$ \\
Peridinium berve & $*$ & $*$ & $*$ \\
Peridinium conicoides & $*$ & & $*$ \\
Peridinium conicum & $*$ & $*$ & $*$ \\
Peridinium crassipes & $*$ & $*$ & $*$ \\
Peridinium depressum & $*$ & $*$ & $*$ \\
Peridinium inflatum & & & $*$ \\
Peridinium islandicum & & $*$ & $*$ \\
Peridinium leonis & $*$ & & $*$ \\
Peridinium pellucidum & $*$ & & $*$ \\
Peridinium subinerme & $*$ & & \\
Peridinium thorianum & $*$ & $*$ & $*$ \\
Peridinium wiesneri & $*$ & & $*$ \\
Peridinium spp. & $*$ & $*$ & $*$ \\
Dinophysis acuta & $*$ & & $*$ \\
Dinophysis fortii & $*$ & $*$ & $*$ \\
Dinophysis ovum & $*$ & & \\
Dinophysis sp. indet. & $*$ & $*$ & $*$ \\
Phalacroma rotundata & & & $*$ \\
& & & \\
$\quad *$ Present & & &
\end{tabular}


The plankton and fossilized cyst assemblages observed at each station are as follows:

St. 1: The plankton assemblage consists mainly of common genera Peridinium and Ceratium. In the former group, Peridinium depressum is predominant and is followed by $P$. thorianum and $P$. conicum.

The fossilized cyst assemblage is very poor because the sediment sample is coarse and sandy. Only a few Peridinium cysts are obtained.

St. 2: The plankton assemblage is almost exclusively made up of Peridinium depressum. Small numbers of Peridinium crassipes and Ceratium spp. are also found. The occurrence of a warm water species, $P$. crassipes, is noteworthy.

The fossilized cyst assemblage is composed of several species of Peridinium cysts, Spiniferites mirabilis, S. ramosus and Operculodinium centrocarpum. It is noticeable that a few specimens of Tuberculodinium vancampoae which is the cyst form of the warm-water species, Pyrophacus vancampoae (Rossignol), were found.

St. 3: At this location a plankton sample was not available.

The fossilized cyst assemblage consists of a few Peridinium cysts, Operculodinium centrocarpum and Spiniferites mirabilis.

St. 4: Just as in the other plankton samples, Peridinium depressum and other Peridinium species make up more than 90 per cent of the plankton population. It is important that many individuals of Peridinium conicoides enveloping the cyst within are found together with some thecate specimens.

Operculodinium centrocarpum occupies more than 60 per cent of the present fossilized cyst population, and Peridinium group makes up 80 per cent of the remaining part. A pelagic cyst form with Gonyaulax type tabulation corresponding to the fossil genus Leptodinium was not found except for a few specimens from this sample.

No cyst form of the genera Ceratium and Dinophysis, commonly occurring dinoflagellates in the surface plankton, was obtained from any present sediment sample. Generally speaking, the dinoflagellate assemblage of both plankton and sediment samples off Hachinohe Coast are characterized by a predominant occurrence of the genus Peridinium, but on the specific level there is a distinct difference between them.

\section{Discussions}

As shown in Table 3 and Text-fig. 2, each thecate assemblage is characterized by an abundant occurrence of Peridinium depressum and very rare occurrence or lack of Gonyaulax and Protoceratium groups. On the other hand, most cyst assemblages are made up of Peridinium conicoides, $P$. ? denticulatum, $P$. sp. cf. $P$. ? denticulatum, $P$. oblongum and $P$. sp. aff. P. oblongum. Furthermore, Operculodinium centrocarpum, a cyst form of the thecate species Protoceratium reticulatum, and Spiniferites, one of the typical cyst forms of thecate genus Gonyaulax, are relatively abundant in the cyst assemblages, although these dinoflagellates were not found from the present thecate assemblages.

The remarkable differences as observed between the living assemblage in the 
water column, the biocoenosis, and the fossilized one in the bottom sediments, the thanatocoenosis, at relatively smaller areas have already been well documented and some possible explanations have been suggested for the differences in the case of other smaller planktonic organisms. As an example for calcareous planktonic foraminifers and coccolithophorids, the differences may result from the following factors: morphological characteristics such as fine spines of planktonic foraminifers, central

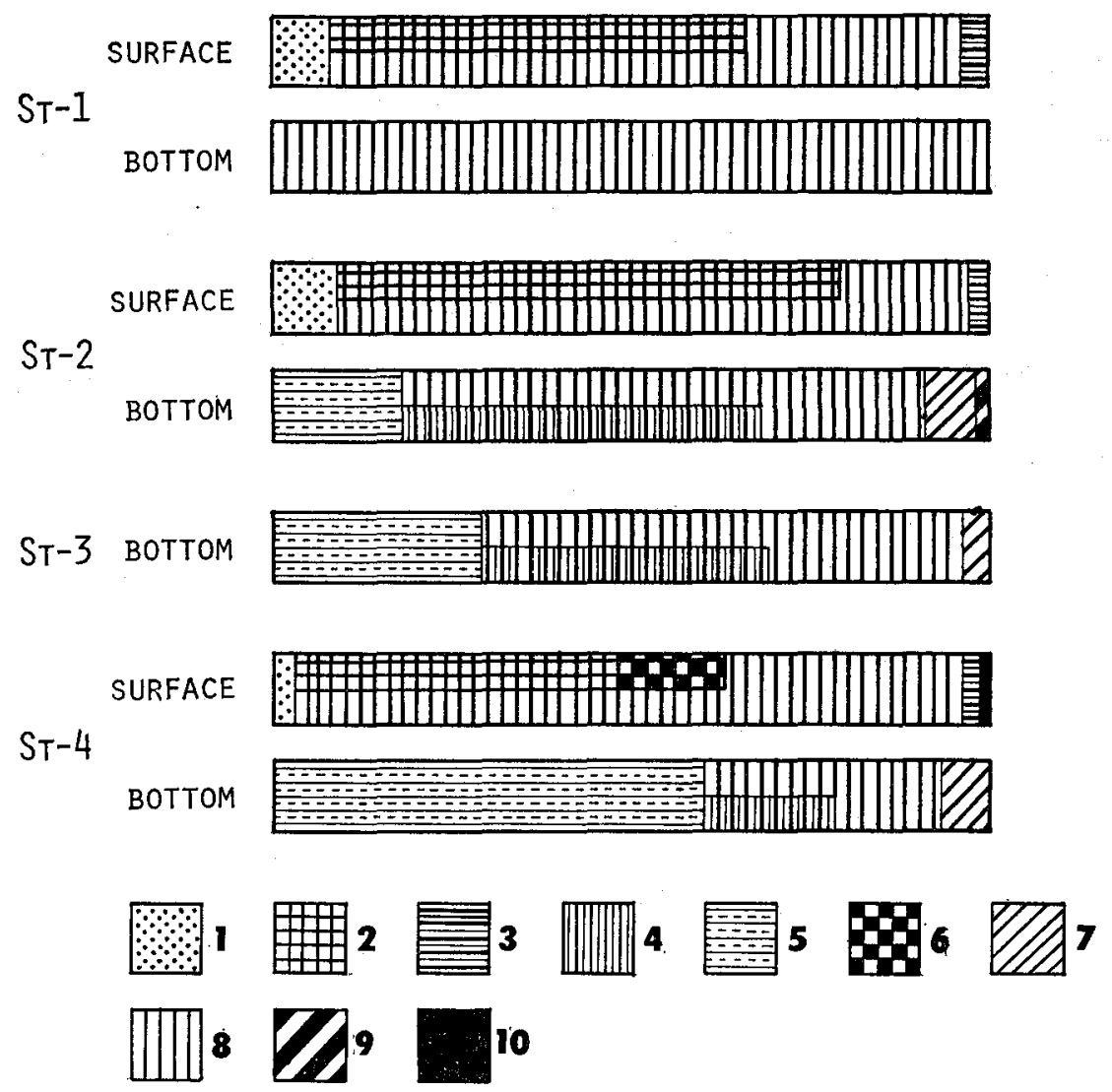

Text-fig. 2. Percentage frequency of thecate and fossilized dinoflagellates in surface plankton and bottom sediments.

1: Ceratium spp., 2: Peridinium depressum, 3: Dinophysis spp., 4: spherical cysts of Peridinium spp. such as Peridinium conicoides, P. ? denticulatum, etc. 5: Operculodinitm centrocarpum, 6: Peridinium conicoides (thecate form), 7: Spiniferites spp., 8: Peridinium spp. 9: Tuberculodinium vancampoae, 10: Diplopsalis lenticula.

bridge structures and arrangement of calcite crystal grains of coccolithophorids, and dissimilarity of CCD in each species (Roth and Berger, 1975).

In the case of the present dinoflagellate assemblages, the following factors may explain the differences. First, as the sampling of planktonic thecate dinoflagellates was carried out only once in a particular season, the obtained result may not necessarily represent the conclusive dinoflagellate assemblages throughout the year. The 
fossilized cyst assemblages in the bottom sediments, on the other hand, seem to show a genaral aspect of cysts produced during the last many years. In addition, some of the cysts may have been transported from other area by ocean currents. Secondly, only certain members of thecate dinoflagellates produce the resting spores but others do not, and at present the cyst-theca relationship of modern dinoflagellates producing spores is not clarified sufficiently. According to the single cell excystment experiments carried out by Wall and Dale (1968, 1969, 1970 and 1971), the cyst-theca relationship of about six genera including ten species of modern dinoflagellates has been established. In Pleistocene sediments, many dinoflagellate cysts have been reported as hystrichospheres (Rossignol, 1964). Reid (op. cits.) discussed the discordant occurrence between planktonic thecate and fossilized cyst forms of modern dinoflagellates around the British Isles. And then he (1974) described many gonyaulacacean dinoflagellate cysts. Those thecate and motile forms, however, have been quite unknown. Furthermore, in such genera as Ceratium, with the exception of a few freshwater species, and Dinophysis, both universally distributed in world oceans, their resting spores have never been clarified.

According to Davey and Rogers (1975), off the southwest coast of South Africa, Operculodinium centrocarpum is associated with the warm-water Agulhas current, while Spiniferites ramosus is associated with the cold-water Benguela current. The same aspect of distrubution of these dinoflagellates was pointed out in the Atlantic region also by Williams (1970).

Around the Japanese Island, two major current systems are present; the warmwater Kuroshio and Tsushima currents on the one hand and the cold-water Oyashio current on the other. The present study area is under the influence of the Tsugaru current which is a branch of warm water divided from the Tsushima current and is streaming from the Sea of Japan through the Tsugaru Strait into the Pacific towards the southern district of Hokkaido and the northeastern district of Honshu. Therefore, the fact that Operculodinium centrocarpum occurred more abundantly than Spiniferites ramosus in the present bottom sediments is concordant with the previous works in the Atlantic and off South Africa.

The general life cycle of dinoflagellates is interpreted by Wall and Dale (op. cits.) as follows: in the favorable condition such as late spring to early summer, the life phase of Gonyaulax, for example, is planktonic with two flagella, many plates and platelets, and much food reserves are accumulated by active photosynthesis. When the environmental condition becomes unfavorable in autumn and winter, the thecate Gonyaulax bears a cyst and takes a benthonic life phase on the shallow sea bottom. Its fossilized hystrichospherid cysts such as Spiniferites and Lingulodinium do not morphologically resemble thecate and motile form at all, and are frequently collected from the bottom sediments in the coastal area. On the other hand, the fossil genus Leptodinium with Gonyaulax type tabulation is mostly obtained from the deep-sea bottom sediments in a pelagic area, and appears to lack a benthonic life phase. But life cycles of modern dinoflagellates have been poorly investigated in the natural state, 
and only a few knowledges are available as to how the encystment cells with protoplasm behave in the water column.

The present findings of Peridinium conicoides at encystment stage covered with thecate wall in the surface plankton sample may throw some light on the understanding of the life cycle of the pelagic species. These encystment specimens were obtained from the plankton sample at St. 2 and St. 4, in which the specimens were relatively abundant. At St. 4 the depth is $1,740 \mathrm{~m}$ and its surface water temperature was $7^{\circ} \mathrm{C}$. Undoubtedly the bottom floor must be aphotic, and its water temperature may be less than $4^{\circ} \mathrm{C}$, possibly throughout seasons. If the encystment cells fall down into such unfavorable environments, it may be impossible for them to germinate and to retake a planktonic life phase. Judging from rare occurrence of these cysts enclosed with thecate wall in the surface plankton at St. 1 and St. 2, the encystment cells of Peridinium conicoides are not considered to have been drived from the photic zone near the coastal area. Therefore, it seems likely that the dinoflagellates with the planktonic life phase distributed in the pelagic zone may take a planktonic resting phase at an encystment stage.

\section{Systematic Description}

Division PYRRHOPHYTA Pascher, 1914

Class DINOPHYCEAE Fritsch, 1929

Order PERIDINIALES Haeckel, 1894

Family Peridiniaceae Ehrenberg, 1832

Genus Peridinium Ehrenberg, 1832

Peridinium conicoides Paulsen, 1905

Pl. II, figs 5-9.

Cyst-form

Chytroeisphaeridea simplica Wall, 1966; p. 308, text-figs. 7, 20.

Peridinium conicoides Paulsen: Wall and Dale, 1968; p. 277, pl. 2, figs. 29, 30.

Description:

The thecate specimens have a slightly tapering apical and two small hollow antapical horns, and are characterized by a sulcal region broadening posteriorly. The cyst enclosed in the thecate wall is dark brownish, mostly circular on lateral view and of thick wall. In the sediment samples collected from St. 1, St. 2, St. 3 and St. 4, these cyst forms are identified with Peridinium conicoides based on the structure of middorsal, intercalary, trapezoidal archeopyle corresponding to plate 2a with two short and four long sides.

Dimension:

Thecate form; length $34-56 \mu$, width $37-56 \mu$.

Cyst form; length 30-40 $\mu$, width $34-46 \mu$. 


\section{Remarks:}

Several thecate forms enclosing resting spores were found together with other planktonic thecate dinoflagellates from St. 2 and St. 4. On the other hand, there are no specimens of thecate forms in the sample at St. 1.

The significance of finding these thecate forms enclosing the resting spores has been already discussed in detail (p. 357-358).

\section{Peridinium? denticulatum Gran and Braarud, 1935}

Pl. III, fig. 12.

Cyst-form

Peridinium?denticulatum Gran and Braarud: Wall and Dale, 1968; p. 277, pl. 3, fig. 30.

Description:

The cyst is spherical, dark brown, and of smooth wall surface and has a hexagonal intercalary archeopyle expanded equatorially.

Dimension :

Cyst diameter $56 \mu-76 \mu$, archeopyle $22 \mu \times 42 \mu$ on an average. Remarks:

The present specimens are slightly larger than those previously described by Wall and Dale (1968); the average diameter is $68 \mu$ in the former and $56 \mu$ in the latter.

\section{Peridinium sp. cf. P.? denticulatum Gran and Braarud, 1935}

$$
\text { Pl. III, fig. } 10
$$

Gyst-form

Cf. Peridinium?denticulatum Gran and Braarud: Wall and Dale, 1968; p. 277, pl. 3, fig. 30.

Description :

The cyst has spherical, dark brownish wall, and a hexagonal anterior intercalary archeopyle with two long and four short sides expanded equatorially.

Dimension:

Cyst diameter $37 \mu$ on an average.

Remarks:

The present specimens are closely similar to Peridinium? denticulatum shown by Wall and Dale (1968) in general shape and its characteristic archeopyle. The former specimens, however, are much smaller than the latter.

Peridinium leonis Pavillard, 1916

$$
\text { Pl. III, fig. } 9
$$

Cyst-form

Peridinium leonis Pavillard: Wall and Dale, 1968; p. 276, pl. 2, figs. 18-21, pl. 3, fig. 22. 
Description:

The cyst is roundly peridinioid in outline and has brownish and smooth wall surface. The epitract is broadly conical in shape. The apex is minutely flattened. Its archeopyle is a single anterior intercalary type corresponding to plate $2 \mathrm{a}$, and roundly pentagonal in shape. The hypotract is tapered toward antapex and has two asymmetrical antapical projections. The girdle region is represented by two parallel ridges well developed.

Dimension:

Cyst length $69 \mu-71 \mu$, width $75 \mu-80 \mu$, diameter of archeopyle $15 \mu-17 \mu \times 13 \mu-15 \mu$. Remarks:

The present specimens from the bottom sediments off Hachinohe are slightly larger than those reported by Wall and Dale (1968). Except for the cyst size, the morphological features, that is the pentagonal intercalary archeopyle, characteristic girdle zone reflected by two parallel ridges, and minutely flattened apex, coincide well with their descriptions.

\section{Peridinium oblongum (Aurivillius) Paulsen, 1907}

P1. III, figs. 2, 3, Pl. IV, figs. 4, 5

Cyst-form

Peridinium sp. (Cyst-forms 1, 3, 4): Wall, 1966; p. 304-307, text-figs. 8, 9, 11, 13-15, 22.

Peridinium oblongum (Aurivillius) Paulsen: Wall and Dale, 1968; p. 272-273, pl. 1, figs. 22-29, pl. 3, figs. 9-11.

Peridinium oblongum (Aurivillius) Paulsen: Davey and Rogers, 1975; pl. 1, fig. 11.

Description:

The test is roundly pentagonal to subconical in shape, and has two distinctive antapical horns with subtriangular to hexagonal intercalary archeopyle corresponding to plate la or $2 \mathrm{a}$.

Dimension:

Cyst length $62 \mu-73 \mu$, width $61 \mu-73 \mu$.

Remarks:

Wall and Dale (1968) divided the cyst forms of Peridinium oblongum into three types on the bases of variation in its apical and antapical regions and general shape. The specimen figured in Pl. III, fig. 2 is assigned to their second type, and another figured specimen (Pl. III, fig. 3) to their third type, respectively.

Peridinium sp. aff. P. oblongum (Aurivillius) Paulsen, 1907

Pl. III, fig. 4

Cyst-form

Gf. Peridinium oblongum (Aurivillius) Paulsen: Wall and Dale, 1968; p. 272-273, pl. 1, fig. 28. 
Description:

The test is generally pentagonal in shape without apical and antapical horns and with dark brownish and smooth cyst wall. Its archeopyle is large, hexagonal and expanded equatorially in shape with some accessory archeopyle sutures.

Dimension:

Cyst length $63 \mu-75 \mu$, width $60 \mu-70 \mu$.

Remarks:

The present specimens are generally similar to the second type of Peridinium oblongum described by Wall and Dale (1968). The former, however, is distinguished from the latter in lacking obvious apical and antapical horns and having a large hexagonal intercalary archeopyle.

Peridinium sp. aff. P. pentagonum Gran, 1902

Pl. III, fig. 8

Cyst-form

Gf. Peridinium sp. cf. P. pentagonum Gran: Wall and Dale, 1968; p. 274-275, pl. 2, figs. 11, 12.

Description:

The cyst is pentagonal on dorso-ventral view and separated equally into epi- and hypotract by well defined girdle without remarkable displacement. The epitract with a short conical apical boss is subroundly triangular in shape. The hypotract has two short but prominent antapical horns and a shallow sulcal region. The colorless cyst wall is ornamented with numerous, short acuminate spines. Each plate boundary is reflected by linear arrangement of these spines.

Dimension:

Cyst length $73 \mu$, width $77 \mu$, length of spines ca. $3 \mu$, antapical horn $4 \mu$. Remarks:

These specimens closely resemble Peridinium sp. cf. $P$. pentagonum described by Wall and Dale (1968), but the latter differs by possessing shorter and intratabular spines.

Peridinium sp. cf. P. punctulatum Paulsen, 1907

Pl. III, fig. 11

Gyst-form

Cf. Peridinium punctulatum Paulsen: Wall and Dale, 1968; p. 276, pl. 2, fig. 27, pl. 3, fig. 25.

Description:

The cyst is spherical, dark brown and with smooth wall surface. Its archeopyle is slightly deformedly hexagonal in shape with two short sides corresponding to the second anterior intercalary plate. 
Dimension:

Cyst diameter $56 \mu-59 \mu$, archeopyle $19 \mu \times 35 \mu$ on an average.

Remarks:

It is very difficult to distinguish the present species from other spherical single walled Peridinium cysts such as Peridinium avellana, $P$. conicoides and $P$. ? denticulatum. They are, however, different in cyst diameter, and provided each with characteristic intercalary archeopyle. Actually in the present work, these spherical cysts cannot be specifically identified.

\section{Peridinium sp. cf. P. subinerme Paulsen, 1904}

P1. III, fig. 1.

Cyst-form

Gf. Peridinium subinerme Paulsen: Wall and Dale, 1968; p. 276, pl. 2, figs. 22-24, pl. 3, fig. 23.

Description:

The test is light brown with medium striation from girdle to polar regions. In polar view, the cyst are cordiform, and dorsal area is much depressed. So the cyst is strongly compressed vertically, the lateral outline is scarcely observed. The epitract may be flat conical shape with concave side line and have small obscure apical projection. The hypotract may somtimes have one or two very small projections. The girdle region is reflected by clear deep furrow and its margin is flange-like and minutely denticulated around the dorsal area. Its relatively large archeopyle in the middorsal surface is roundly hexagonal in shape and may be corresponding to the second anterior intercalary plate.

Dimension:

Cyst diameter; right to left $55 \mu-83 \mu$, ventral to dorsal $54 \mu-74 \mu$, archeopyle $22 \mu-29 \mu \times 28 \mu-30 \mu$.

Remarks :

The present specimens are closely similar to the cyst form of Peridinium subinerme in general shape and in archeopyle type. The former, however, are distinct from the latter in possessing the striated wall surface, denticulated margin of the girdle on the dorsal side and stronger depression in the apical to antapical direction. Moreover, the former are larger than the latter in cyst diameter.

\section{Peridinium sp. (Cyst-form A) \\ Pl. III, fig. 7}

Description :

The dorso-ventral view is roundly pentagonal in shape. The wall surface is characterized by irregular wrinkles, and dark brown in color. In the apical region, the present specimens are provided with a broad but small projection. Two asymmetrical 
antapical projections are observed, and relatively narrow and shallow longitudinal furrow is developed in the sulcal region. Its archeopyle may be an intercalary type corresponding to the plate $2 \mathrm{a}$, and trapezoidal in shape.

Dimension:

Cyst length $57 \mu-77 \mu$, width $60 \mu-75 \mu$.

Remarks:

The present specimens resemble the cyst of Peridinium claudicans in the general outline of the dorso-ventral view and in the shape of archeopyle. According to Wall and Dale (1968), however, Peridinium claudicans produces a cyst covered with numerous short point-like spines. Also, the cyst of $P$. oblongum is distinguished from the present specimens in having smooth and thin wall and a deep antapical sulcus.

\section{Peridinium sp. (Cyst-form B)}

Pl. III, fig. 5.

\section{Description:}

The test with an inner capsule is a peridinioid shape with a truncated epitract. The outer wall is light brown, thin and of smooth surface; the inner capsule is dark brown in color. The outer body has two short asymmetrical antapical projections and relatively deep sulcus. Its archeopyle may be a large one and of combination type composed of apical and anterior intercalary plates. The upper part of the inner capsule is subspherical, but the lower part has two roundish projections such as those of the outer body. Also, there is a narrow sulcus in the lower part of the capsule. The opening of the inner capsule is not clear.

Dimension:

Outer wall; length $52 \mu$, width $56 \mu$. Inner capsule; length $45 \mu$, width $49 \mu$. Remarks:

Only a single specimen has been obtained from the bottom sediment at St. 4 . This specimen is characterized by having an inner capsule. Modern Peridinium cysts possessing an inner capsule such as observed in fossil genera Deflandrea and $W_{e-}$ tzeliella have been reported by Eisenack and Fries (1965), Evitt and Wall (1968), and Wall and Dale (1968). Those cysts are produced by freshwater species, Peridinium limbatum and $P$. wisconsinense. Their inner capsule is spherical to subspherical in shape and lacks a sulcus in the antapical region. The present specimen is noteworthy in having the inner capsule with a narrow sulcus.

\section{? Peridinium sp. (Cyst-form C)}

Pl. III, fig. 13.

\section{Description:}

This specimen is a half pentagonal cyst ornamented with numerous and relatively 
long acuminate spines, and provided with two asymmetrical projections in the hypotract.

Dimension:

Cyst length $56 \mu$, width $50 \mu$, antapical projection ca. $10 \mu$, length of spine ca. $12 \mu$. Remarks :

According to its general shape and two asymmetrical projections, the present cyst seems to belong to a species of Peridinium.

\section{Peridinium sp. (Cyst-form D)}

Pl. III, fig. 6.

\section{Description:}

The specimens with smooth, dark brown and single layered wall are roughly pentagonal in shape. The trapezoidal hypotract has a moderately deep ventral sulcus and the epitract has the trapezoidal archeopyle reflected by the second anterior intercalary plate in mid-dorsal position. They have an obvious ridged girdle zone. Dimension:

Cyst length $45 \mu-63 \mu$, width $49 \mu-65 \mu$, archeopyle $19 \mu-24 \mu \times 15 \mu-19 \mu$. Remarks:

The present specimens represent a general resemblance to the cyst form of Peridinium sp. 1 described by Wall and Dale (1968), but differ from the latter in the shape of the archeopyle and the epitract.

Family Protocerataceae Lindemann, 1928

Cyst-genus Operculodinium Wall, 1967

\section{Operculodinium centrocarpum (Deflandre and Cookson) Wall, 1967}

$$
\text { Pl. II, fig. } 10
$$

Hystrichosphaeridium centrocarpum Deflandre and Cookson, 1955: p. 272-273, pl. 8, figs. 3, 4.

Baltisphaeridium centrocarpum (Defl. and Cook.) Downie and Sarjeant: Brosius, 1963; p. 44, pl. 6, fig. 6, text-fig. $8 \mathrm{a}, \mathrm{b}$.

Protoceratium reticulatum Claparede and Lachmann: Evitt and Davidson, 1964; p. 5, pl. 1, fig. 12.

Operculodinium centrocarpum (Defl. and Cook.) Wall, 1967: p. 111, pl. 16, figs. 1, 2, 5.

Operculodinium centrocarpum (Defl. and Cook.) Wall: Harland, 1973; p. 236-239, pl. II, figs. 4, 7-16, pl. III, figs. 1-6, pl. IV, figs. 1, 2.

Description:

Operculodinium centrocarpum, the cyst form of Protoceratium reticulatum, has a spherical body covered with numerous nontabular capitate processes. Its archeopyle is of a precingular type.

Dimension:

Cyst diameter $24 \mu-35 \mu \times 26 \mu-39 \mu$, length of processes $4 \mu$ on an average. 


\section{Remarks:}

This species makes up 20 per cent to 60 per cent of the thanatocoenosis population of the bottom sediments at St. 2 and St. 4. But none was sampled at St. 1. In the surface plankton at St. 4, a few specimens of Operculodinium centrocarpum enclosing the protoplasts with dark brown thick wall are found. These specimens are smaller than the excystment forms with the precingular archeopyle taken from the bottom sediments.

Family Pyrophacaceae Lindemann, 1928

Cyst-genus Tuberculodinium Wall, 1967

Tuberculodinium vancampoae (Rossignol) Wall, 1967

=Pyrophacus vancampoae (Rossignol) Wall and Dale, 1971

Pl. II, fig. 11

Pterospermopsis ? van campoae Rossignol, 1962: p. 134, pl. 2, fig. 1.

Tuberculodinium vancampoae (Rossignol) Wall, 1967: p. 114-115, pl. 16, figs. 15, 16 .

Pyrophacus vancampoae (Rossignol) Wall and Dale, 1971: p. 234-235, figs. 19-25.

Description:

The discoidal cyst is composed of two wall layers. The inner wall of ca. $1.5 \mu$ in thickness makes up the central body with smooth and brown surface. There are short, stout and hollow tuberculate processes which support the thin fragile outer wall. These processes have an open distal end of the trampet shape. Its archeopyle is a peculiar type corresponding to a few posterior antapical plates (Wall and Dale, 1971).

Dimension:

Over all diameter of cyst $90 \mu-116 \mu$, diameter of central body $63 \mu-82 \mu$, length of processes $27 \mu-34 \mu$.

Remarks:

Wall and Dale (1971) carried out a minute single cell incubation experiment with Pyrophacus horologicum, P. steinii and P. vancampoae (motile and thecate form of Tuberculodinium vancampoae). As one of the results, it is clarified that only Pyrophacus vancampoae among them has a characteristic hystrichosphaerid cyst. In the present area, a few specimens of Tuberculodinium vancampoae were obtained.

Family Gonyaulacaceae Lindemann, 1928

Cyst-genus Spiniferites Mantell, 1850 emend. Sarjeant, 1970

Spiniferites bulloideus (Deflandre and Cookson) Reid and Downie, 1973

Pl. II, fig. 12 
Hystrichosphaera bulloidea Deflandre and Cookson, 1955: p. 264, pl. 5, figs. 3, 4.

Spiniferites bulloideus (Defl. and Cook.) Reid and Downic, 1973, p. 316.

\title{
Spiniferites ramosus (Ehrenberg) Loeblich and Loeblich, 1966
}

\author{
P1. II, fig. 13
}

Hystrichosphaera ramosa (Ehr.) O. Wetzel: Davey and Williams, 1966; p. 32, pl. 1, figs. 1, 6, text-fig. 8. Hystrichosphaera furcata (Ehr.) O. Wetzel: Wall, 1967; p. 99-100, pl. 14, figs. 1, 2, text-fig. 2. Spiniferites ramosus (Ehr.) Loeblich and Loeblich, 1966: p. 56-57

\section{Acknowledgements}

Sincere gratitude is extended to Dr. Shiro Nishida of the Nara University of Education for providing the samples and various encouragements. The writer cordially thanks Dr. Saburo Nishimura of the Seto Marine Biological Laboratory, Kyoto University, for his kindness in giving him the opportunity of publishing the paper and for a critical reading of the manuscript, and Mr. Saburo Toriumi of the Yokohama Municipal Higashi Senior High School for helpful advice in the identification of thecate dinoflagellates. $\mathrm{He}$ is also grateful to Mr. Kenichi Harada of the Kyoto University for his useful discussion, and to Professor Shohei Kokawa and Professor Kazuo Huzita of the Osaka City University for their continuous encouragements.

\section{REFERENCES}

Boulouard, C. et Delauze, H. 1966. Analyse palynoplanktologique de sédiments prélevés par le bathyscaphe "Archeimède" dans la fosse du Japon. Marine Geol., vol. 4, p. 461-466, pls. 2.

Brosius, M. 1963. Plankton aus dem nordhessischen Kasseler Meeressand (ober Oligozän). Z. dt, geol. Ges., vol. 114, p. 32-56, pl. 1-8, text-figs. 1-2, tables 1-2.

Davey, R.J. and Rogers, J. 1975. Palynomorph distribution in Recent offshore sediments along two traverses off Southwest Africa. Marine Geol., vol. 18, p. 213-225, pI. 1, figs. 1-2.

and Williams, G.L. 1967. The genera Hystrichosphaera and Achomosphaera. British Mus. (Nat. Hist.) Bull., Geol. Suppl. 3, p. 28-52, figs. 8-12, tables 2.

Deflandre, G. and Cookson, I.C. 1955. Fossil microplankton from Australian late Mesozoic and Tertiary sediments. Aust. J. Mar. Freshw. Res., vol. 6, no. 2, p. 242-313, pl. 1-9, text-figs. 1-59, table 1 .

Eisenack, A. and Fries, M. 1965. Peridinium limbatum (Stokes) Verglichen mit der tertiären Deflandrea phosphoritica Eisenack. Geologiska Föreninges i Stokholm Forhandlinger, vol. 87, p. 239-248, text-figs. 1-2.

Evitt, W.R. 1963. A discussion and proposals concerning fossil Dinoflagellates, Hystrichospheres and Acritarchs. Nat. Acad. Sci., Proc., vol. 49, p. 158-164 and p. 298-302, text-figs. 1-4.

- and Davidson, S.E. 1964. Dinoflagellate studies I. Dinoflagellate cysts and theca. Stanford Univ., Puble. Geol. Sci., vol. 10, no. 1, p. 1-12, pl. 1, text-figs. 1-2.

- and Wall, D. 1968. Dinoflagellate studies IV. Theca and cyst of recent freshwater Peridinium limbatum (Stokes) Lindemann. Ibid, vol. 12, no. 2, p. 1-15, pl. 1-4.

Harada, K. 1974. Distribution of fossil microplankton in surface sediments on the continental margin of the Pacific off Japan. Master thesis of Kyoto Univ. (MS.), p. 1-25, pl. 1-5, table 1.

Harland, R. 1973. Quaternary (Flandrian?) dinoflagellate cysts from the Grand Banks, off Newfoundland, Canada. Rev. Palaeobotan. Palynol., vol. 16, p. 229-242, pl. 1-5, fig. 1.

Locblich, A.R. Jr. and Locblich A.R. III. 1999. Index to the genera subgenera and sections of the Pyrrhophyta. Miam. Univ. Inst. Mar. Sci. Stud. Trop. Oceanogr., no. 3, p. 1-94. 
Matsuoka, K. and Nishida, S. 1973. Fossil microplankton in the bottom sediments around the Tosabae and Kii Channel, off Shikoku. Abstract, Geol. Soc. Japan, Ann. Meeting, Sendai, p. 115.

Reid, P.G. 1972. Dinoflagellate cyst distribution around the British Isles. J. mar. biol. Ass. U. K., vol. 52, p. 939-944, figs. 1-3.

1974. Gonyaulacacean dinoflagellate cysts from the British Isles. Nova Hedwigia, vol. 25, nos. $3+4$. p. 579-937, pl. 1-4, text-figs. 1-15.

and Downie, G. 1973. The age of the Bridlington Crag. Proc. Yorkshire Geol. Soc., vol. 39 , pt. 3, no. 15 , p. $315-318$, tables 2 .

Rossignol, M. 1962. Analyse pollinique de sédiments marins quaternaries en Israël, II. Sédiments pléistocenès. Pollen et Spores, vol. 4, p. 121-148, pl. 1-2, tables 1-2.

___ 1964. Hystrichosphères du Quaternarie en Méditerranée orientale, dans les séditmens pléistocènes et les boues marines actuelles. Rev. Micropaléont., vol. 7, no. 2, p. 83-99, pl. 1-3, figs. A-H.

Roth, P.H. and Berger, W.H. 1975. Distribution of coccoliths in the south and central Pacific. p. 87-113, text-figs. 1-24: in Sleiter, W.V., Be, A.W.H. and Berger, W.H. (edt.) Dissolution of deep-sea carbonates. Cushman Found. Foram. Res., Spec. Publ. no. 13.

Sarjeant, W.A.S. 1970. The genus Spiniferites Mantell, 1850 (Dinophyceac). Grana, vol. 10, p. 7478.

1974. Fossil and living dinoflagellates. pp. 179, Academic Press, London.

Shimakura, M. 1970. Pollen analysis of the bottom sediments in the Japan Sea. Gircular "Nihonkai", no. 5, p. 27-30.

Wall, D. 1966. Modern hystrichospheres and dinoflagellate cysts from the Woods Hole region. Grana Palynologica, vol. 6, no. 2, p. 297-314, figs. 1-29.

-1967. Fossil microplankton in deep-sea cores from the Caribbean Sea. Palaeontology, vol. 10, pt. 1, p. 95-123, pl. 14-16, text-figs. 1-8.

__ and Dale, B. 1967. The resting cysts of modern dinoflagellates and their paleontological significance. Rev. Palaeobotan. Palynol., vol. 2, p. 349-354, pl. 1.

and - 1968. Modern dinoflagellate cysts and evolution of the Peridiniales. Micropaleontology, vol. 14, no. 3, p. 265-304, pl. 1-4, text-figs. 1-7, tables 1-2.

—_ and 1969. The hystrichosphaerid resting spore of the dinoflagellate Pyrodinium bahamense Plate, 1906. Jour. Phycology, vol. 5, no. 2, p. 140-149, figs. 1-34, table 1.

_- 1970 . Living hystrichosphaerid dinoflagellate spores from Bermuda and Puerto Rico. Micropaleontology, vol. 16, no. 1, p. 47-58, pl. 1.

— and 1971. A reconsideration of living and fossil Pyrophacus Stein, 1833 (Dinophyceae). Jour. Phycology, vol. 7, no. 3, p. 221-235, figs. 1-40.

_ _ - - and Harada, K. 1973. Description of new fossil dinoflagellates from the Late Quaternary of the Black Sea. Micropaleontology, vol. 19, no. 1, p. 18-31, pl. 1-3, text-fig. 1, table 1 .

Williams, D.B. 1971. The occurrence of dinoflagellates in marine sediments. In Funnel, B.M. and Riedel, W.R. (eds.). The Micropaleontology of Oceans, p. 231-243, figs. 1-11. 


\section{EXPLANATION OF PLATES I-IV}

\section{Plate I}

Fig. 1. Peridinium wiesneri Schiller, $\times 560$, Loc. St. 4 .

Fig. 2. Peridinium conicum (Gran) Ostenfeld \& Schmidt, $\times 560$, Loc. St. 4.

Fig. 3. Peridinium leonis Pavillard, $\times 560$, Loc. St. 1.

Fig. 4. Peridinium pellucidum (Berg) Schutt, $\times 560$, Loc. St. 1.

Fig. 5. Peridinium subinerme Paulsen, $\times 560$, Loc. St. 1 .

Fig. 6. Peridinium breve Paulsen, $\times 560$, Loc. St. 4 .

Fig. 7. Peridinium thorianum Paulsen, $\times 560$, Loc. St. 4 .

Fig. 8. Peridinium crassipes Kofoid, $\times 560$, Loc. St. 2 .

Fig. 9. Peridinium depressum Bailey, $\times 560$, Loc. St. 1 .

Fig. 10. Peridinium sp. indet., $\times 560$, Loc. St. 1 .

Fig. 11. Peridinium inflatum Okamura, $\times 560$, Loc. St. 1.

Fig. 12. Peridinium islandicum Paulsen, $\times 560$, Loc. St. 2 .

All specimens collected from surface water.

\section{Plate II}

Fig. 1. Ceratium arcticum (Ehrenberg) Cleve, $\times 300$, Loc. St. 2.

Fig. 2. Dinophysis acuta Ehrenberg, $\times 560$, Loc. St. 4 .

Fig. 3. Dinophysis fortii Pavillard, $\times 560$, Loc. St. 1 .

Fig. 4. Dinophysis sp. indet., $\times 560$, Luc. St. 4 .

Figs. 5-9. Peridinium conicoides Paulsen, encystment cell covered with thecate plates: 5 \& 6 ; same specimen, $\times 560$, Loc. St. $4: 7 ; \times 560$, Loc. St. $4: 8 ; \times 560$, Loc. St. $4: 9 ; \times 560$, Loc. St. 4.

Fig. 10. Operculodinium centrocarpum (Deflandre \& Cookson) Wall=cyst form of Protoceratium reticulatum (Claparede \& Lachmann) Butschli, $\times 560$, Loc. St. 2; encystment stage.

Fig. 11. Tuberculodinium vancampoae (Rossignol) Wall=cyst form of Pyrophacus vancampoae (Rossignol) Wall \& Dale, $\times 380$, Loc. St. 2.

Fig. 12. Spiniferites bulloideus (Deflandre \& Cookson) Reid \& Davey=one of cyst forms of Gonyaulax scrippsae Kofoid, $\times 560$, Loc. St. 2.

Fig. 13. Spiniferites ramosus (Ehrenberg) Loeblich \& Loeblich=one of cyst forms of Gonyaulax spinifera (Claparede \& Lachmann) Diesing, $\times 560$, Loc. St. 2.

Specimens of figs. 1-9 collected from surface plankton. Specimens of figs. 10-13 taken from bottom sediments.

\section{Plate III}

Fig. 1. Peridinium sp. cf. P. subinerme Paulsen, $\times 560$, Loc. St. 2.

Figs. 2 \& 3. Peridinium oblongum (Aurivillius) Paulsen, $\times 560,2$; Loc. St. 2 , 3; Loc. St. 4 .

Fig. 4. Peridinium sp, aff. P. oblongum (Aurivellius) Paulsen, $\times 560$, Loc. St. 2.

Fig. 5. Peridinium sp. (Cyst-form B), $\times 560$, Loc. St. 4.

Fig. 6. Peridinium sp. (Cyst-form D), $\times 560$, Loc. St. 4.

Fig. 7. Peridinium sp. (Cyst-form A), $\times 560$, Loc. St. 4.

Fig. 8. Peridinium sp. aff. P. pentagonum Gran, $\times 560$, Loc. St. 4.

Fig. 9. Peridinium leonis Pavillard, $\times 560$, Loc. St. 2.

Fig. 10. Peridinium sp. cf. P. ? denticulatum Gran \& Braarud, $\times 560$, Loc. St. 4.

Fig. 11. Peridinium sp. cf. $P$. punctulatum Paulsen, $\times 560$ Loc. St. 4.

Fig. 12. Peridinium ? denticulatum Gran \& Braarud, $\times 560$, I.oc. St. 2.

Fig. 13. ? Peridinium sp. (Cyst-form C), $\times 560$, Loc. St. 4 .

All specimens taken from bottom sediments. 


\section{Plate IV}

Figs. 1-3. Peridinium depressum Bailey, Loc. St. 1. 1; obliquer ventral view, $\times 550,2$; enlargement of Plate 1"' $\times 2300,3$; apical view, $\times 410$.

Figs. 4-5. Peridinium oblongum (Aurivillius) Paulsen (Cyst form), Loc. St. 4, dorsal view, reflected girdle shown by slight depression of wall, $\times 670,5$. enlargement of archeopyle, accessory archeopyle sutures. $\times 2700$

Fig. 6. Ceratium bucephalum (Cleve) Cleve, Loc. St. $1, \times 380$.

Fig. 7. Peridinium leonis Pavillard, Loc. St. $1, \times 630$.

All figures by scanning electron microscope. 
Publ. Seto Mar.: Biol. Lab., XXIII (3/5), 1976
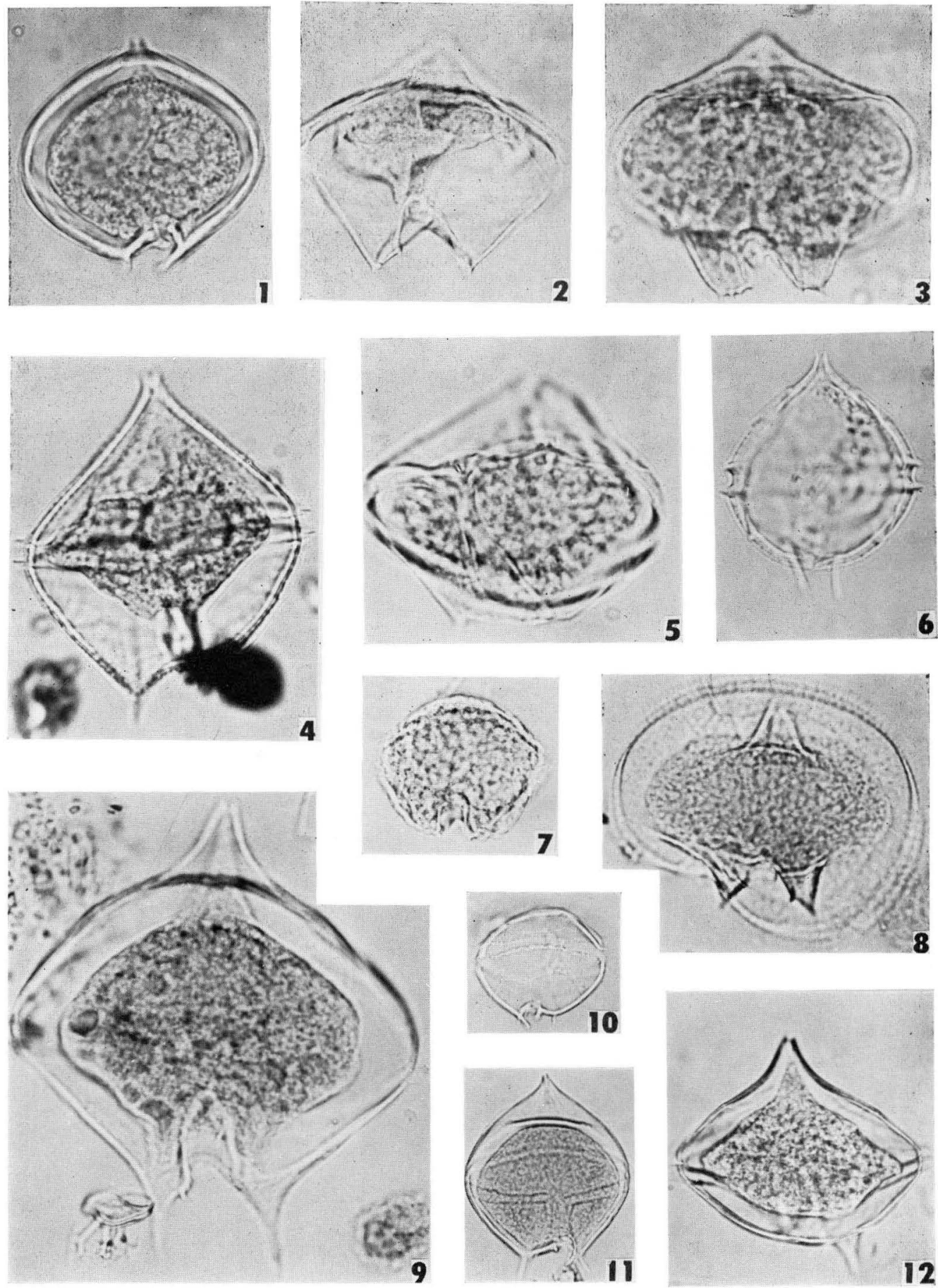

K. Matsuoka: Recent Thecate and Fossilized Dinoflagellates 
Publ. Seto Mar. Biol. Lab., XXIII (3/5), 1976
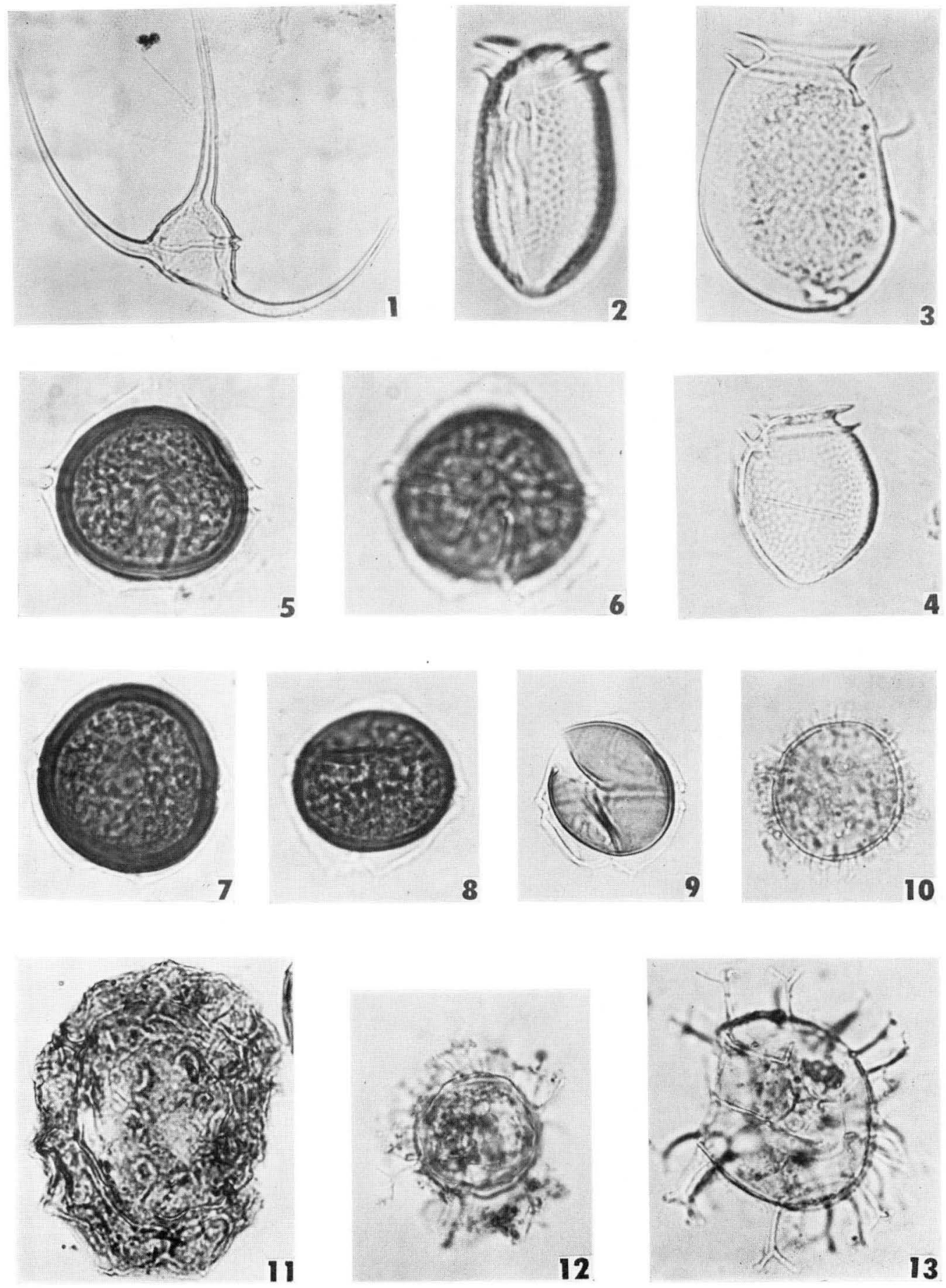

K. Matsuoka: Recent Thecate and Fossilized Dinoflagellates 
Publ. Seto Mar. Biol. Lab., XXIII (3/5), 1976
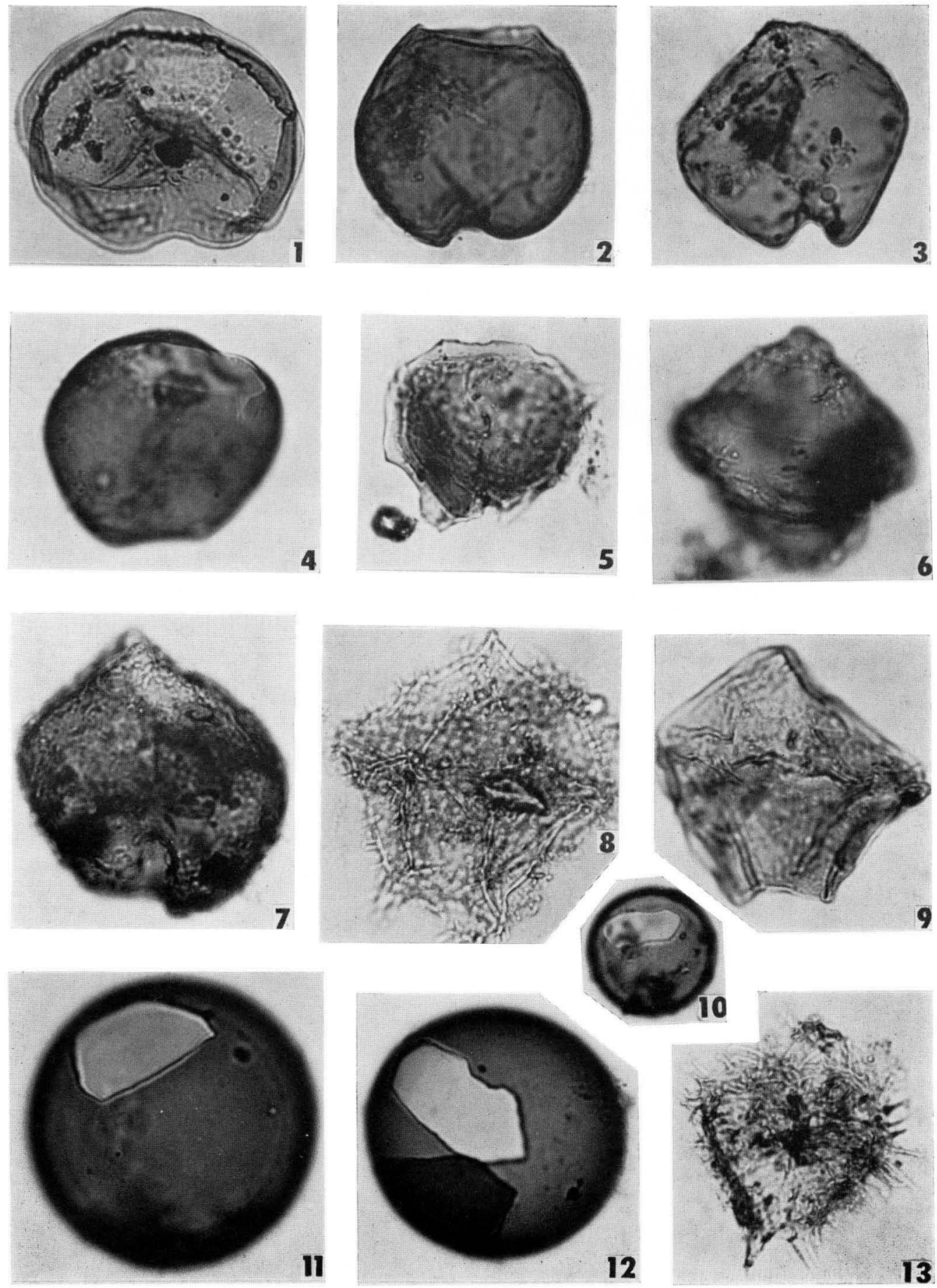

K. Matsuoka: Recent Thecate and Fossilized Dinoflagellates 
Publ. Seto Mar. Biol. Lab., XXIII (3/5), 1976
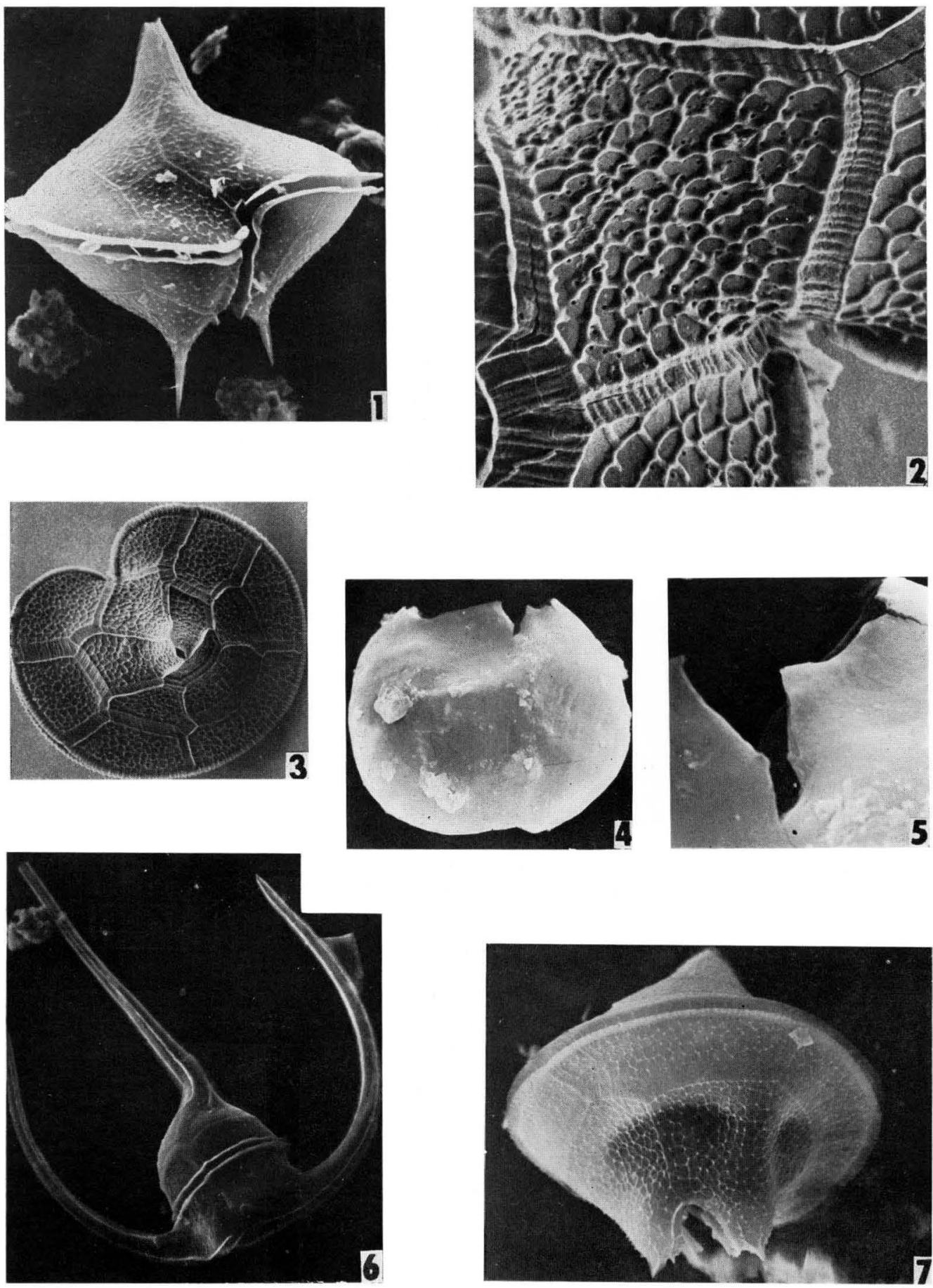

K. Matsuoka: Recent Thecate and Fossilized Dinoflagellates 